Original Research Article

\title{
Analysis of price variation of some commonly used antibacterial agents
}

\author{
Rohan Srivastava*, Naresh D. Kantharia
}

Department of Pharmacology, Government Medical College, Surat, Gujrat, India

Received: 13 April 2019

Revised: 09 June 2019

Accepted: 11 June 2019

*Correspondence to:

Dr. Rohan Srivastava,

Email: drrohan_30@

rediffmail.com

Copyright: (C) the author(s), publisher and licensee Medip Academy. This is an openaccess article distributed under the terms of the Creative Commons Attribution NonCommercial License, which permits unrestricted noncommercial use, distribution, and reproduction in any medium, provided the original work is properly cited.

\begin{abstract}
Background: Antimicrobial resistance is a serious problem. Resistance may develop due to irrational use including poor patient compliance due to prescription of expensive drugs. In present study, the variation in the price of commonly used antibacterial was analysed.

Methods: The price of commonly used antibacterial agents listed in recent issues of CIMS and MIMS was analysed in respect of number of brands available, price range (10 tablets or capsules) and 1 ampoule or vial (parenteral preparation) i.e. minimum, maximum and average price and price ratio (maximum/minimum). FDCs and formulation with only 1-2 brands were excluded.

Results: The number of brands of oral antibacterial agents varied from 3 (faropenem $200 \mathrm{mg}$ ) to 90 (azithromycin $500 \mathrm{mg}$ ). The maximum price variation amongst different brands was 21.64 for levofloxacin $500 \mathrm{mg}$ followed by 14.28 and 11.26 for linezolid $600 \mathrm{mg}$ and moxifloxacin $400 \mathrm{mg}$ respectively. For parenteral preparations, the number of brands varied from 2 (gentamicin $80 \mathrm{mg}$ ) to 57 (ceftriaxone $1 \mathrm{~g}$ ). The maximum price variation was 5.05 for meropenem 1 $\mathrm{g}$ followed by 3.69 and 2.63 for meropenem $500 \mathrm{mg}$ and ceftriaxone $1 \mathrm{~g}$ respectively.

Conclusions: A very wide price variation was observed amongst different brands of both oral and parenteral formulations of antibacterial agents. Prescribing expensive brands may lead to resistance due to poor patient compliance.
\end{abstract}

Keywords: Antimicrobial agents, Cost analysis, Outcomes research, Pharmacoeconomics, Price variation

\section{INTRODUCTION}

Antimicrobial agents (AMAs) are very important with regard to cure of disease. In spite of great advancement in medical sciences still very few diseases are curable with drugs due to availability of effective antimicrobial agents. It has been found that most of the infectious disease are curable if treated with rationality. AMAs are costlier preparation and studies have shown that doctors are often not aware or do not pay much attention to, the cost of antibiotics which they are prescribing and do not realize the unnecessary impact on patient finances. ${ }^{1-3}$ Moreover, little attention has been paid to cost variation amongst different brands from reputed pharmaceuticals. Different brand of a generic drug is expected to provide same quality of treatment, but indiscriminate use of AMAs may cause various problems that include antimicrobial resistance and adverse drug reactions. The emergence of antimicrobial resistance is a serious problem. To prevent the resistance, guidelines to use antibiotics and antibiotic policy were introduced from time to time by the concerned regulatory authorities.

Resistance may develop due to irrational use; this includes poor patient compliance (adherence to treatment) because patient may not complete the course of treatment, if expensive drugs are prescribed. The price of various drugs can be compared including comparison amongst different brands to provide the best treatment with minimum cost i.e. cost minimization analysis as a part of outcomes 
research i.e. pharmacoeconomics. ${ }^{4,5}$ Few studies are available with regard to analysis of price variation amongst AMAs.

In present study, the variation in the price of commonly used antibacterial was analyzed in current scenario to ascertain the rational drug therapy with regard to prescription of economical drugs.

\section{METHODS}

The price of commonly used antibacterial agents listed in recent issues of CIMS (January to March 2017) and MIMS (March 2017) was analyzed.

\section{Inclusion criteria}

The antibacterial included in the analysis were oral preparations of 4-fluoroquinolones (4-FQs), $\beta$-lactam antibiotics, tetracyclines, macrolides and miscellaneous antibiotics, injectable $\beta$-lactam antibiotics and aminoglycosides and other commonly used injectable antibacterial agents. Only single agent formulations were included.

\section{Exclusion criteria}

Fixed dose combinations of antibacterial were excluded in the study. The formulations having only one to two brands and rarely used and newer antibacterial were also excluded.

The formulations were analyzed in respect of number of brands available, price range (10 tablets or capsules) and 1 ampoule or vial (parenteral preparation) i.e. minimum, maximum and average price and price ratio (maximum/minimum). The average price was calculated by adding the price of all the available brands of an antibacterial agent and divided by number of brands. Price variation was determined to know the difference between costlier and cheaper drug.

\section{RESULTS}

The number of brands of oral 4-FQs varied from 7 (norfloxacin $400 \mathrm{mg}$ ) to 58 (levofloxacin $500 \mathrm{mg}$ ) (Table 1 ). The number of brands of oral $\beta$-lactam range from 3 (faropenem $200 \mathrm{mg}$ ) to 59 (cefixime $200 \mathrm{mg}$ ) (Table 2).

Table 1: Variation in the price of some commonly used 4-fluoroquinolones (oral preparation).

\begin{tabular}{|c|c|c|c|c|c|}
\hline \multirow{2}{*}{ Antibacterial agent } & \multirow{2}{*}{ No. of brands } & \multicolumn{2}{|c|}{ *Price range (INR) } & \multirow{2}{*}{$\begin{array}{l}\text { Average } \\
\text { price }\end{array}$} & \multirow{2}{*}{$\begin{array}{l}\text { Price ratio } \\
\text { maximum/minimum }\end{array}$} \\
\hline & & Minimum & Maximum & & \\
\hline Norfloxacin 400mg & 7 & 12.37 & 68 & 27.32 & 5.49 \\
\hline Ciprofloxacin $250 \mathrm{mg}$ & 33 & 21.95 & 59.80 & 29.2 & 2.72 \\
\hline Ciprofloxacin 500mg & 41 & 41 & 70 & 54.5 & 1.70 \\
\hline Ofloxacin $200 \mathrm{mg}$ & 48 & 28 & 310 & 52.3 & 11.0 \\
\hline Ofloxacin 400mg & 32 & 53.26 & 530 & 74.4 & 9.95 \\
\hline Sparfloxacin $200 \mathrm{mg}$ & 19 & 57.2 & 291.6 & 95.6 & 5.09 \\
\hline Moxifloxacin 400mg & 12 & 71 & 800 & 465.7 & 11.26 \\
\hline Levofloxacin 250mg & 39 & 30 & 74.5 & 42.4 & 2.48 \\
\hline Levofloxacin 500mg & 58 & 45 & 974 & 82.5 & 21.64 \\
\hline Gemifloxacin 320mg & 16 & 99 & 580 & 252.8 & 5.85 \\
\hline
\end{tabular}

*For a unit of 10 tablets or capsules; INR-Indian rupee

Table 2: Variation in the price of some commonly used oral $\beta$-lactam antibiotics.

\begin{tabular}{|c|c|c|c|c|c|}
\hline \multirow[t]{2}{*}{ Antibacterial agent } & \multirow[t]{2}{*}{ No. of brands } & \multicolumn{2}{|c|}{ *Price range (INR) } & \multirow{2}{*}{$\begin{array}{l}\text { Average } \\
\text { price }\end{array}$} & \multirow{2}{*}{$\begin{array}{l}\text { Price ratio } \\
\text { maximum/minimum }\end{array}$} \\
\hline & & Minimum & Maximum & & \\
\hline Ampicillin $250 \mathrm{mg}$ & 5 & 17.42 & 69.50 & 30.9 & 3.98 \\
\hline Ampicillin $500 \mathrm{mg}$ & 5 & 32.40 & 89.50 & 58.0 & 2.76 \\
\hline Amoxicillin $250 \mathrm{mg}$ & 19 & 30.00 & 69.00 & 41.3 & 2.3 \\
\hline Amoxicillin $500 \mathrm{mg}$ & 34 & 56.30 & 113.00 & 72.5 & 2.00 \\
\hline Cephalexin $250 \mathrm{mg}$ & 10 & 47.60 & 89.00 & 61.5 & 1.86 \\
\hline Cephalexin $500 \mathrm{mg}$ & 12 & 88.70 & 169.95 & 98.2 & 1.90 \\
\hline Cefadroxil $500 \mathrm{mg}$ & 09 & 33.10 & 70.6 & 43.8 & 2.13 \\
\hline Cefuroxime axetil $50 \mathrm{mg}$ & 51 & 99 & 399 & 218.4 & 4.03 \\
\hline Cefuroxime axetil $500 \mathrm{mg}$ & 57 & 98 & 862.50 & 348.2 & 8.80 \\
\hline Cefixime $200 \mathrm{mg}$ & 59 & 54 & 198 & 95.4 & 3.66 \\
\hline Cefpodoxime $200 \mathrm{mg}$ & 57 & 70.67 & 269 & 125.6 & 3.80 \\
\hline Faropenem 200mg & 03 & 317 & 361 & 345 & 1.13 \\
\hline
\end{tabular}

*For a unit of 10 tablets or capsules; INR-Indian rupee 
Table 3: Variation in the cost of some commonly used tetracyclines, macrolides and miscellaneous antibiotics (oral preparation).

\begin{tabular}{|c|c|c|c|c|c|}
\hline \multirow{2}{*}{ Antibacterial agent } & \multirow{2}{*}{ No. of brands } & \multicolumn{2}{|c|}{ *Price range (INR) } & \multirow{2}{*}{$\begin{array}{l}\text { Average } \\
\text { price }\end{array}$} & \multirow{2}{*}{$\begin{array}{l}\text { Price ratio } \\
\text { maximum/minimum }\end{array}$} \\
\hline & & Minimum & Maximum & & \\
\hline Doxycycline $100 \mathrm{mg}$ & 8 & 6.15 & 44 & 18.9 & 7.15 \\
\hline Minocycline $100 \mathrm{mg}$ & 5 & 249 & 460 & 282.8 & 1.85 \\
\hline Clarithromycin $250 \mathrm{mg}$ & 16 & 70 & 433.25 & 286.7 & 6.18 \\
\hline Clarithromycin $500 \mathrm{mg}$ & 12 & 250 & 930 & 548.4 & 3.72 \\
\hline Roxithromycin $150 \mathrm{mg}$ & 20 & 52 & 145 & 72.4 & 2.78 \\
\hline Azithromycin $250 \mathrm{mg}$ & 88 & 65 & 147 & 82.6 & 2.26 \\
\hline Azithromycin $500 \mathrm{mg}$ & 90 & 160 & 358.30 & 278.4 & 2.24 \\
\hline Clindamycin $150 \mathrm{mg}$ & 6 & 130 & 294.50 & 178 & 2.26 \\
\hline Clindamycin 300mg & 10 & 151.50 & 394 & 252.5 & 2.60 \\
\hline Linezolid $600 \mathrm{mg}$ & 24 & 70 & 1000 & 527.3 & 14.28 \\
\hline
\end{tabular}

*For a unit of 10 tablets or capsules; INR-Indian rupee

Table 4. Variation in the cost of commonly used injectable $\beta$-lactam antibiotics.

\begin{tabular}{|c|c|c|c|c|c|}
\hline \multirow{2}{*}{ Antibacterial agent } & \multirow{2}{*}{ No. of brands } & \multicolumn{2}{|c|}{ *Price range (INR) } & \multirow{2}{*}{ Average price } & \multirow{2}{*}{$\begin{array}{l}\text { Price ratio } \\
\text { maximum/minimum }\end{array}$} \\
\hline & & Minimum & Maximum & & \\
\hline Cefotaxime $250 \mathrm{mg}$ & 11 & 12.92 & 28.50 & 16.5 & 2.20 \\
\hline Cefotaxime $500 \mathrm{mg}$ & 9 & 17.31 & 44.66 & 26.2 & 2.58 \\
\hline Ceftriaxone $250 \mathrm{mg}$ & 45 & 28.38 & 35.50 & 32.6 & 1.25 \\
\hline Ceftriaxone $500 \mathrm{mg}$ & 37 & 35.00 & 65.00 & 48.2 & 1.85 \\
\hline Ceftriaxone $1 \mathrm{gm}$ & 57 & 46.95 & 123.75 & 76.4 & 2.63 \\
\hline Cefoperazone $1 \mathrm{gm}$ & 3 & 156 & 295 & 228.6 & 1.89 \\
\hline Ceftazidime $250 \mathrm{mg}$ & 6 & 67.41 & 132.10 & 85.65 & 1.95 \\
\hline Ceftazidime $1 \mathrm{gm}$ & 12 & 229.20 & 457 & 362.4 & 1.99 \\
\hline Meropenem 500 mg & 10 & 349 & 1290 & 879 & 3.69 \\
\hline Meropenem $1 \mathrm{gm}$ & 26 & 592 & 2990 & 1802.6 & 5.05 \\
\hline Aztreonem $1 \mathrm{gm}$ & 5 & 450 & 940 & 628.5 & 2.08 \\
\hline Ertapenem 1 gm & 3 & 2400 & 2450 & 2425 & 1.02 \\
\hline Doripenem $500 \mathrm{mg}$ & 4 & 3200 & 4449 & 3646.6 & 1.39 \\
\hline
\end{tabular}

*For one ampoule or vial; INR-Indian rupee

Table 5: Variation in the price of aminoglycosides and other commonly used injectable antibacterial.

\begin{tabular}{|c|c|c|c|c|c|}
\hline \multirow{2}{*}{ Antibacterial agent } & \multirow{2}{*}{ No. of brands } & \multicolumn{2}{|c|}{ *Price range (INR) } & \multirow{2}{*}{ Average price } & \multirow{2}{*}{$\begin{array}{l}\text { Price ratio } \\
\text { maximum/minimun }\end{array}$} \\
\hline & & Minimum & Maximum & & \\
\hline Amikacin $250 \mathrm{mg}$ & 23 & 24.90 & 39.00 & 28.6 & 1.56 \\
\hline Amikacin $500 \mathrm{mg}$ & 26 & 38.55 & 83.00 & 62.4 & 2.15 \\
\hline Gentamicin $40 \mathrm{mg}$ & 3 & 7.21 & 7.81 & 7.48 & 1.08 \\
\hline Gentamicin $80 \mathrm{mg}$ & 2 & 7.26 & 8.02 & 7.64 & 1.10 \\
\hline Tobramycin $80 \mathrm{mg}$ & 4 & 48.00 & 80.00 & 61.1 & 1.66 \\
\hline Netilmicin $25 \mathrm{mg}$ & 5 & 46.60 & 59.50 & 52.1 & 1.27 \\
\hline Netilmicin $50 \mathrm{mg}$ & 5 & 86.75 & 110.00 & 99.65 & 1.26 \\
\hline Vancomycin $500 \mathrm{mg}$ & 7 & 250 & 389 & 336.4 & 1.55 \\
\hline Teicoplanin $400 \mathrm{mg}$ & 6 & 1267 & 1676.70 & 1429.2 & 1.32 \\
\hline Clinadamycin $300 \mathrm{mg}$ & 7 & 82.50 & 131 & 102.3 & 1.58 \\
\hline Clinadamycin $600 \mathrm{mg}$ & 7 & 155 & 282 & 208 & 1.81 \\
\hline
\end{tabular}

*For one ampoule or vial; INR-Indian rupee 
Considering the oral preparation of tetracyclines, macrolides and miscellaneous antibiotics, the number of brands varied from 5 (minocycline $100 \mathrm{mg}$ ) to 90 (azithromycin $500 \mathrm{mg}$ ) (Table 3). Overall, the number of brands of oral antibacterial agents varied from 3 (faropenem $200 \mathrm{mg}$ ) (Table 2) to 90 (azithromycin 500 $\mathrm{mg}$ ) (Table 3). For parenteral preparations of $\beta$-lactam the number of brands varied from 3 (cefoperazone $1 \mathrm{~g}$ and ertapenem $1 \mathrm{~g}$ ) to 57 (ceftriaxone $1 \mathrm{~g}$ ) (Table 4); and parenteral preparation of aminoglycosides the number of brands varied from 2 (gentamicin $80 \mathrm{mg}$ ) to 26 (amikacin $500 \mathrm{mg}$ ) (Table 5).

Regarding the price variation, the maximum price variation amongst different brands of oral formulation was 21.64 for levofloxacin $500 \mathrm{mg}$ (Table 1) followed by 14.28 and 11.26 for linezolid $600 \mathrm{mg}$ (Table 3 ) and moxifloxacin $400 \mathrm{mg}$ (Table 1) respectively. For parenteral preparations, the maximum price variation was 5.05 for meropenem $1 \mathrm{~g}$ (Table 4) followed by 3.69 and 2.63 for meropenem 500 $\mathrm{mg}$ and ceftriaxone $1 \mathrm{~g}$ (Table 4 ) respectively.

\section{DISCUSSION}

In the present study, the main objective was to analyse the cost variation amongst various brand of generic antimicrobials manufactured by pharmaceuticals and widely prescribed by clinicians. The study has revealed a very wide variation/range in the minimum and maximum price amongst different brands of AMAs available in India.

One of the important causes of poor patient compliance is high cost of treatment leading to relapse and antimicrobial resistance. The number of brands/formulation of AMAs available in India ${ }^{6}$ is high with very wide variation in their cost. Incomplete information to prescribers, government regulations including drug pricing policies and economic interest of pharmaceuticals (profit making, certain targets) also contribute to prescription of costlier drugs. ${ }^{7-9}$

The problem can be overcome if AMAs are prescribed by (a) generic names and/or (b) prescribing cheapest available brand. ${ }^{10}$ Prescription of cheapest brand is only possible when proper training is given to doctors during their formative years as doctors particularly interns are not aware about cot of drug., ${ }^{1,2}$ Thus, teaching of pharmacoeconomics must be included in undergraduate medical curriculum ${ }^{11}$ and training should be given to interns and residents.

The training should also lay emphasis on evaluation of new AMAs from formularies and drug promotional literature. ${ }^{12,13}$ Awareness and training to clinicians will reduce the cost of treatment of infectious disease as shown by certain studies. ${ }^{14}$ One study has shown that maximum price was twice than minimum for oral AMAs. Sharref et $\mathrm{al}^{15}$ Showed price variation of 3.7 times for single parenteral antibiotic. ${ }^{16}$
Another study revealed that costliest brand were sold more than the cheapest brands; and there was tendency to prescribe costlier AMAs. ${ }^{3}$ Appropriate measures should be taken by doctors, pharmacists and drug regulators should assess the maximum variation in price of a drug and fix the price accordingly with rationality. ${ }^{17}$

\section{CONCLUSION}

A very wide price variation was observed amongst different brands of both oral and parenteral formulations of antibacterial. Thus, it is recommended to prescribe generic drugs or drugs with lowest price/with average price, in case of doubt in bioavailability. Moreover. There is need to create awareness amongst the clinicians and residents regarding prescribing of cheaper brands of AMAs.

\section{Funding: No funding sources}

Conflict of interest: None declared

Ethical approval: The study was approved by the Institutional Ethics Committee

\section{REFERENCES}

1. Kaine RE, O'connel EJ. Physicians appreciation of drug charges to the patient. Clin. Pediatr (Phila). 1972;11:664-72.

2. Lowy DR, Lowy L, Warner RS. A survey of physicians' awareness of drug costs. Academic Medicine. 1972 May 1;47(5):349-51.

3. Das SC. A critical study on availability and price variation between different brands: impact on access to medicines. Ind $\mathrm{J}$ Pharmaceutical Sci. 2007;69(1):160.

4. Ahuja J, Gupta M, Gupta AK, Kohli K. Pharmacoeconomics. National Med J Ind. 2004;17(2):80-3.

5. Trask L. Pharmacoeconomics: Principles, methods, and applications. In: DiPiro JT, Talbert RL, Yee GC, Matzke GR, Wells BG, Posey L, eds. Pharmacotherapy: a pathophysiologic approach. $8^{\text {th }}$ Ed. New York: McGraw-Hill. 2011;1972(47):349355.

6. Thomas M. Rational drug use and essential drug concept. In: Parthasarthi G, Nyfort-Hasen K. eds. A textbook of clinical pharmacy practice. $1^{\text {st }}$ Ed. Hyderabad: Orient Longman;2004:72-73.

7. Sarkar PK. A rational drug policy. Ind J Med Ethics. 2004;1(1):11-2.

8. Roy V, Rewari S. Ambiguous drug pricing: a physician's dilemma. Ind J Pharmacol. 1998;30(6):404.

9. Wertheimer AI, Grumer SK. Overview of international pharmacy pricing. Pharmacoeconomics. 1992;2(6):449-55.

10. Horwitz BA, Morgan JF, Fleckenstein L. Saving from generic prescriptions: a study of 33 pharmacies in Rochster, New York. Ann Intern Med. 1973;82(5):601-7. 
11. Ferguson RP. Training the residents to meet the detail man. JAMA. 1989;261(7):992-3.

12. Herxheimer A, Lionel NDW. Minimum pinformation needed by prescribers. BMJ. 1978;2(6145):129-32.

13. Stimson GV. Information contained in durg advertisements. BMJ. 1975;4(5995):508-9.

14. Frazier LM, Brown JT, Divine GW, Fleming GR, Philips NM, Siegal WC, et al. Can physician education lower the cost of prescription drugs? a prospective, controlled trial. Ann Inte Med. 1991;115(2):116-21.

15. Panth N, Paudel R, Chaudhary B, Thapa KK. A study of the pricing variability among the oral antibiotics available in western region hospital- a context of Nepal. World J Pharmacy Pharmaceut Sci. 2014;3(3):1529-35.
16. Sharref J, Mateti VM, James JB, Rao, D, Sharon MS, Samaga L. Analysis of price variation among parenteral antibiotics available in a tertiary care teaching hospital. J Patient Safety Infection control. 2017;5(2):89-93.

17. Patel D, Thiyagu R, Surulivelrajan M, Patel H, Pandey $\mathrm{S}$. Price variability among the oral antibiotics available in a South Indian Tertiary Care Hospital. J Clin Diagnos Res. 2009;3(6):1871-5.

Cite this article as: Srivastava R, Kantharia ND. Analysis of price variation of some commonly used antibacterial agents. Int J Basic Clin Pharmacol 2019;8:1567-71. 